\title{
[原著論文]
}

\section{障害物の影響を考慮した マニピュレータの可操作度}

古荘純次*日井広幸*佐野明人*

マニピニレータの制御あるいは作業計画に際して, 手先効果器の操作性能を定量的に表す尺度があれば有用で ある. 本報告では, 障害物のある環境下に拉けるマニピュレータの能力を運動学的な見地から評価する一つの方 法を提案する.

マニピュレータに接近した障害物は，マニピニレータの運動に多くの拘束を与える. 本報告では，二つの場合 を扱5.一つは，障害物を避けるために関節速度べクトルが等式拘束を満たさねばならない場合である. 他の一 つは, 障害物に接近する速度が制限される場合である. 各々の場合に対して, 著者らは可操作性棈円体および可 操作度を導いた．最後に一つの例として，8自由度を持つマニピュレータを用いて行った実験およびシミュレー ションを示す.この実験では, 狭いスリットを通して手先効果器を差し込み, 本報告で提案した可操作度を大き な値に保ちながら関節角速度が制御される。

\section{1. はじめに}

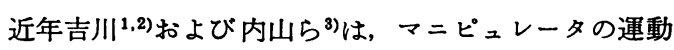
学的な操作性を表す尺度として可操作度 (あるいは機構 性能の評価）の概念を提案した. この概念は，マニピュ レータの機構評価や, 対象物をどの位置に置けば作業性 が良いかを評価する有効な指標となる.

さらに，無人搬送車などの移動ロボットにマニピュレ 一タが搭載されている場合や，マニピュレータが工場内 のレール上を移動して作業する場合に, どの位置で止め て作業をすれば良いかを決める際にも有効な指標となる。 また，圥長性を有するマニピュレータにおいては，そ の自由度に怙けるて長性を利用して作業性がよい姿勢を 保ちながら作業を行うことも可能であるが，その際の作 業性の評価関数としても使うことができる

本研究では，障害物が存在する環境下におけるマニピ こレータの運動学的な操作性を定量的に表す 1 つの方法 を提案する. 障害物の存在する環境下では，マニピュレ 一タの運動に拘束が生じ，その操作性が著しく低下する ことがある.このような時, 障害物がない場合と較べて 問題が複雑であるため, その運動学的な操作性を直感的 に判断することは非常に難しくなる. そこで, その操作 性を定量的に評価することが，障害物の存在する環境下 では特に重要になる.

原稿受付 1987 年 9 月 16 日

* 岐皋大学工学部
2 節では, 基本的な式の定義について述べ，さらにマ ニピニレータの操作性に関して従来得られた結果 ${ }^{1 \sim 4)} の$ らちで, 本研究の議論を進める上で必要となる可操作性 棈円体について簡単に述へる. 本研究では, この可操作 性楕円体の概念を，障害物のある環境下におけるマニピ ニレータの操作性を評価するために扗張する.障害物ゆ えに生じる拘束条件としては次の二つの場合を考えた。

3 節では, スリットにマニピュレータを差し込みなが ら作業をする場合のよらに, マニピニレータの関節速度 が等式の拘束を満たさねばならない場合を考え, この時 の可操作性棈円体および可操作度の誘導法を与えた.

4 節では，障害物方向への速度が零ではなく，ある範 囲内であれば許される場合を考え，この時の可操作性棈 円体および可操作度の誘導法を与えた.

5 節では, 8 リンクマニピュレータに対して, 本研究 で提案した可操作度を適用し, 可操作度が大きくなるよ らに制御実験した一つの例を示す.

\section{2. 障害物がない時の可操作性棈円体及 び可操作度}

$n$ 自由度を有するマニピュレータに対し, その第 $\mathrm{i}$ 関 節の関節变数を $\theta_{\imath}$, その関節ベクトルを

$$
\boldsymbol{\theta}=\left[\theta_{1}, \theta_{2}, \cdots, \theta_{n}\right]^{T}
$$

とする. また手先効果器の位直及び姿勢を示すか次べク トルを

$$
\boldsymbol{x}=\left[x_{1}, x_{2}, \cdots, x_{m}\right]^{T}
$$


とする. 多くの場合 $m=n$ であるが, $m<n$ の場合も あり,このときマニピュレータは圥長性を持つと言われ る.

関節ベクトル $\boldsymbol{\theta}$ が決まると， $\boldsymbol{x}$ は一意に決まるので， その関係を次のように表すことにする.

$$
\boldsymbol{x}=\boldsymbol{f}(\theta)
$$

このとき, 各関節の速度と手先効果器の速度の関係は次 のように表される.

$$
\dot{\boldsymbol{x}}=J(\boldsymbol{\theta}) \dot{\boldsymbol{\theta}}
$$

ここで, $J(\boldsymbol{\theta})=\partial \boldsymbol{f}(\boldsymbol{\theta}) / \partial \boldsymbol{\theta} \in R^{m \times n}$ である.

関節速度べクトル $\dot{\boldsymbol{\theta}}$ が手先効果器にどのような影響を 与えるかを評価するため, 吉川 ${ }^{1,2)}$, 内山ら ${ }^{3)}$ は次のよう な方法を提案し，そのマニピュレータ機構の評価及び制 御への応用について興味深い議論をしている.ここでは, 本研究における議論を進める上で必要な要点を吉川の議 論に従ってまとめておく.

$$
\|\dot{\boldsymbol{\theta}}\|=\sqrt{\dot{\theta}_{1}^{2}+\dot{\theta}_{2}^{2}+\cdots+\dot{\theta}_{n}^{2}} \leqq 1
$$

を満足するよらな関節速度 $\dot{\boldsymbol{\theta}}$ を用いて実現することので きる手先効果器の速度 $\dot{\boldsymbol{x}}$ のすべてからなる集合

$$
S=\{\dot{\boldsymbol{x}} \mid \dot{\boldsymbol{x}}=J \dot{\boldsymbol{\theta}},\|\dot{\boldsymbol{\theta}}\| \leqq 1\}
$$

を考える. この集合 $S$ の形から, 手先効果器がどのよう に動き得るかが分かる.

（6）式から分かるように，集合 $S$ は楕円体である. 楕円体の形を示すには，その主軸を用いて表すのがもっ とも明確である. 主軸を求めるため， $J$ を次のように特 異值分解尚する. たたし, $\operatorname{rank} J=m$ とする.

$$
J=U \Sigma V^{T}
$$

ここで

$$
\begin{aligned}
& \Sigma=\left(\begin{array}{ccccc}
\sigma_{1} & & & & \vdots \\
& \sigma_{2} & & & \vdots \\
& & \cdots & & \vdots \\
& & \cdots & \vdots
\end{array}\right) \in R^{m \times n} \\
& \sigma_{1} \geqq \sigma_{2} \geqq \cdots \geqq \sigma_{m} \geqq 0 \\
& U=\left[\boldsymbol{u}_{1}, \boldsymbol{u}_{2}, \cdots, \boldsymbol{u}_{m}\right]
\end{aligned}
$$

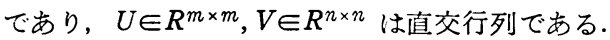

（7）式について考えると， $V^{T}$ は直交行列であるか ら座標の回転を意味し， $\Sigma$ は各座標軸方向に適当な倍率 だけ伸縮させることを意味し，Uは直交行列であるので 適当な角度たけ回転させることを意味する，すなわち，

(6) 式の集合 $S$ は, $\|\dot{\boldsymbol{\theta}}\| \leqq 1$ で与えられる単位球を回転 し，各座標軸方向に伸縮し，さらにUだけ回転すること によって得られるので, その主軸と $\sigma_{1} \boldsymbol{u}_{1}, \sigma_{2} \boldsymbol{u}_{2}, \cdots, \sigma_{m} \boldsymbol{u}_{m}$ とする棈円体であることが分かる.

吉川はこの棈円体に可操作性棈円体という名前を付け た 1,2).この棈円体を直接図示することによってマニピ
ニレータの可操作性を表現できるのは, $m$ が 3 以下の場 合に限られる. そこで, 情報を 1 つのスカラ量に圧縮し て表すことが提案されている.

一つは, この棈円体の体積 $V$

$$
V=\left\{\pi^{m / 2} / \Gamma[(m / 2)+1]\right\} \sigma_{1} \sigma_{2} \cdots \sigma_{m}
$$

を（あるいは，それに対応する $\sigma_{1} \sigma_{2} \cdots \sigma_{m}$ を）評価とす る方法 ${ }^{1 \sim 3)}$ であり, 他の一つは条件数尚

$$
c\left(J^{T}\right)=\sigma_{1} / \sigma_{m}
$$

を評価とする方法4である.

このように, 実現可能な手先効果器の速度 $\dot{\boldsymbol{x}}$ の集合を 楕円体で表すと，スカラ值の評価が簡単に求まるという 利点もある.

\section{3. 関節速度が等式拘束を満たす必要がある 場合の可操作性榜円体およひ可操作度}

例えば Fig. 1 に示すよらに, 狭いスリットに3リン クアームを差し込んで, アームをスリットの中央に保持 しながら作業をするとき，関節速度は次式を満たす必要 がある。

$$
b_{1} \dot{\theta}_{1}+b_{2} \dot{\theta}_{2}+b_{3} \dot{\theta}_{3}=0
$$

ここで

$$
\left\{\begin{array}{l}
b_{1}=c_{12} y_{s}-c_{12} l_{1}+s_{12} x_{s} \\
b_{2}=c_{12} y_{s}-c_{12} l_{1}+s_{12} x_{s}-c_{2} l_{2} \\
b_{3}=0
\end{array}\right.
$$

であり, $l_{1}, l_{2}$ は第 1 , 第 2 リンクの長さ, $\left(x_{s}, y_{s}\right)$ は スリット中央の座標, $s_{12}, c_{2}, c_{12}$ はそれぞれ $\sin \left(\theta_{1}+\right.$ $\left.\theta_{2}\right), \cos \left(\theta_{2}\right), \cos \left(\theta_{1}+\theta_{2}\right)$ を意味する.

このような場合を一般的に表すと

$$
B \dot{\boldsymbol{\theta}}=0, B \in R^{r \times n}
$$

となる.ただし $\operatorname{rank} B=r, n-r \geqq m$ とする.

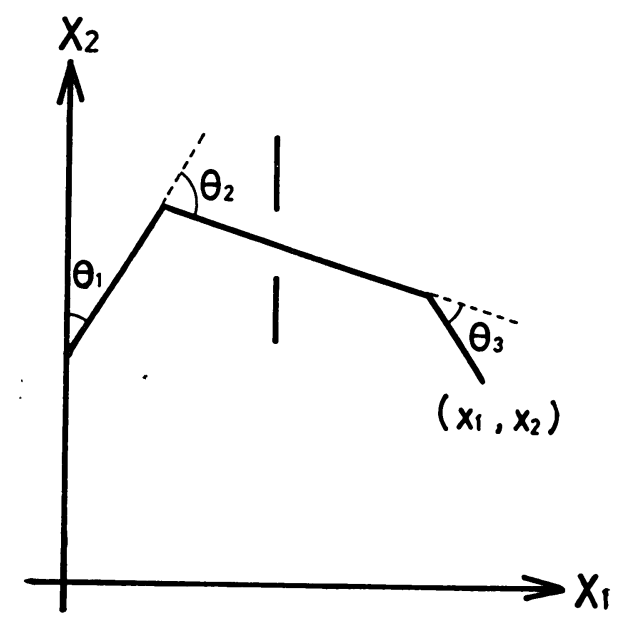

Fig. 13 -link Manipulator $\left(l_{1}=0.6, l_{2}=0.85\right.$, $l_{3}=0.3$ ) 


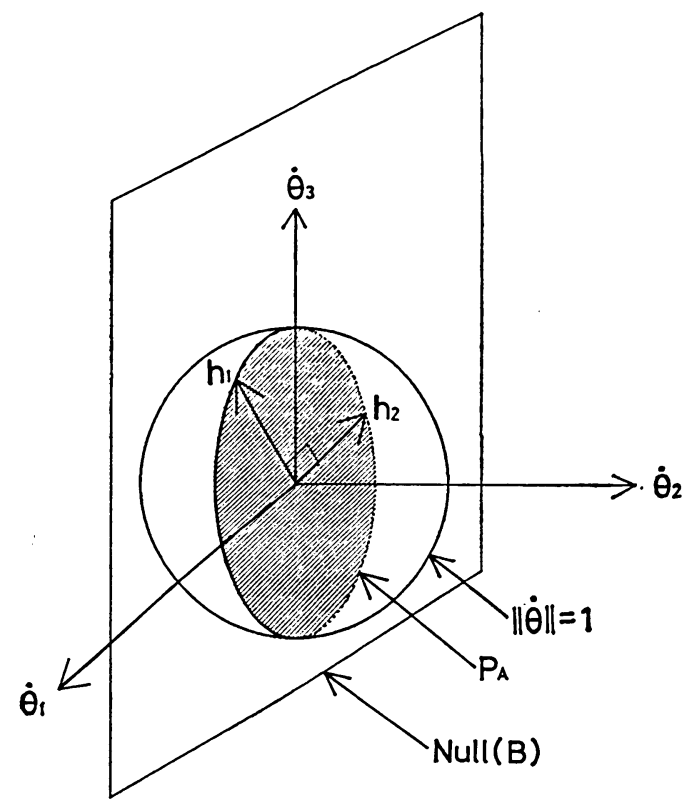

Fig. 2 Set of Admissible Joint Velocity Vectors, $P_{A}$

本節では，関節速度ベクトルが（14）式のような拘束 条件下にあるときの可操作性棈円体について考える.

前節の議論では, 許容される関節速度べクトル $\dot{\boldsymbol{\theta}}$ の集

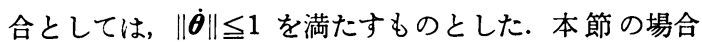
には,さらに (14) 式も満たす必要があるので, 許容さ れる関節速度ベクトルの集合 $P_{A}$ は次のように定義さ れる。

$$
\begin{aligned}
P_{A} & =\{\dot{\boldsymbol{\theta}} \mid B \dot{\boldsymbol{\theta}}=0\} \cap\{\dot{\boldsymbol{\theta}} \mid\|\dot{\boldsymbol{\theta}}\| \leqq 1\} \\
& =\operatorname{Null}(B) \cap\{\dot{\boldsymbol{\theta}} \mid\|\dot{\boldsymbol{\theta}}\| \leqq 1\}
\end{aligned}
$$

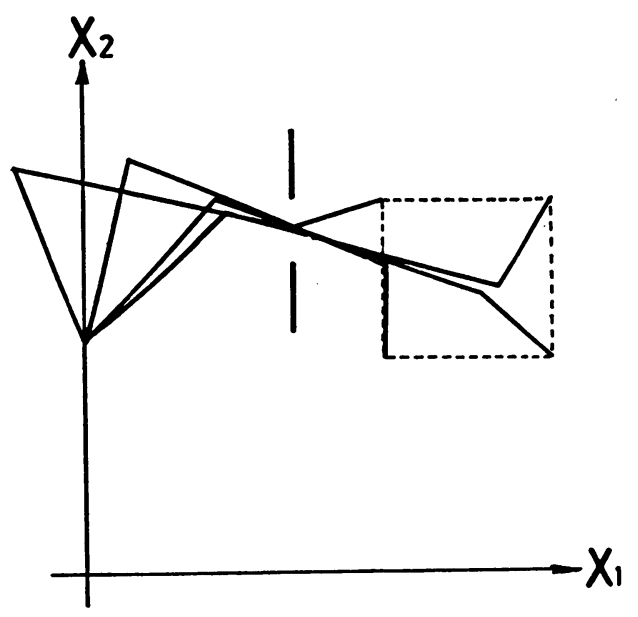

(a) Arm Posture
たたし， $\operatorname{Null}(B)$ は $B$ の零空間を意味する.

Fig. 1 のシステムの場合には $n=3, r=1$ なので, Null (B) や $P_{A}$ は, Fig. 2 に示すように与えられる.

次に，(15）式による $P_{A}$ の定義を，より簡単な式で 置き換えることにする. そのため，部分空間 $\operatorname{Null}(B)$ について考える. $\operatorname{rank} B=r$ なので $\operatorname{dim} \operatorname{Null}(B)=n$ $-r$ である. $\operatorname{Null}(B)$ の正規直交基底を適当に選び $h_{1}$, $\boldsymbol{h}_{2}, \cdots, \boldsymbol{h}_{n-r}$ とする. このとき， $\operatorname{Null}(B)$ に含まれる任 意の完は次のように表すことができる.

$$
\begin{gathered}
\dot{\boldsymbol{\theta}}=\boldsymbol{h}_{1} \boldsymbol{z}_{1}+\boldsymbol{h}_{2} \boldsymbol{z}_{2}+\cdots+\boldsymbol{h}_{n-r} \boldsymbol{z}_{n-r}=H z \\
H=\left[\boldsymbol{h}_{1}, \boldsymbol{h}_{2}, \cdots, \boldsymbol{h}_{n-r}\right] \\
\boldsymbol{z}=\left[\boldsymbol{z}_{1}, \boldsymbol{z}_{2}, \cdots, \boldsymbol{z}_{n-r}\right]^{T}
\end{gathered}
$$

また, $\boldsymbol{h}_{1}, \boldsymbol{h}_{2}, \cdots, \boldsymbol{h}_{n-r}$ の正規直交性より次式が成り立 つ.

$$
\begin{aligned}
\|\dot{\boldsymbol{\theta}}\|^{2} & =\left(\boldsymbol{h}_{1} z_{1}+\cdots+\boldsymbol{h}_{n-r} \boldsymbol{z}_{n-r}\right)^{T} \cdot\left(\boldsymbol{h}_{1} z_{1}+\cdots+\boldsymbol{h}_{n-r} z_{n-r}\right) \\
& =\boldsymbol{z}_{1}{ }^{2}+\boldsymbol{z}_{2}{ }^{2}+\cdots+\boldsymbol{z}^{2}{ }_{n-r} \\
& =\|z\|^{2}
\end{aligned}
$$

そこで，（15）式で定義される $P_{A}$ は次のようにも表す ことができる.

$$
P_{A}=\{\dot{\boldsymbol{\theta}} \mid \dot{\boldsymbol{\theta}}=H z,\|z\| \leqq 1\}
$$

$P_{A}$ に含まれる関節速度ベクトル $\dot{\boldsymbol{\theta}}$ によって夷現する ことができる手先効果器の速度べクトル $\dot{\boldsymbol{x}}$ のすべてから なる集合は次のように表される.

$$
S_{A}=\{\dot{\boldsymbol{x}} \mid \dot{\boldsymbol{x}}=J H z,\|z\| \leqq 1\}
$$

前節の議論, および (6) 式と（21）式の比較から分 かるように, $S_{A}$ は棈円体であり，その主軸は次のよう に与えられる.ただし, $\operatorname{rank} J H=m$ とする.

$J H$ を次のように特異值分解する.

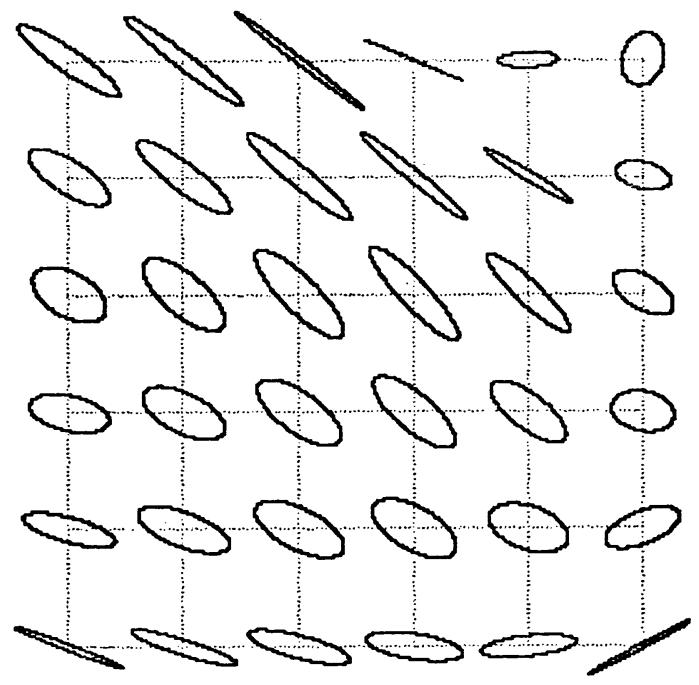

(b) Manipulability Ellipsoid, $S_{A}$

Fig. 3 3-link Manipulator Inserted through a Narrow Slit 


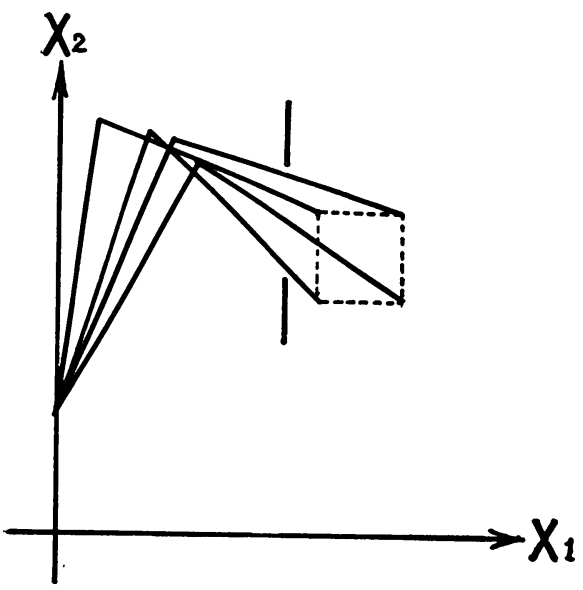

(a) Arm Posture

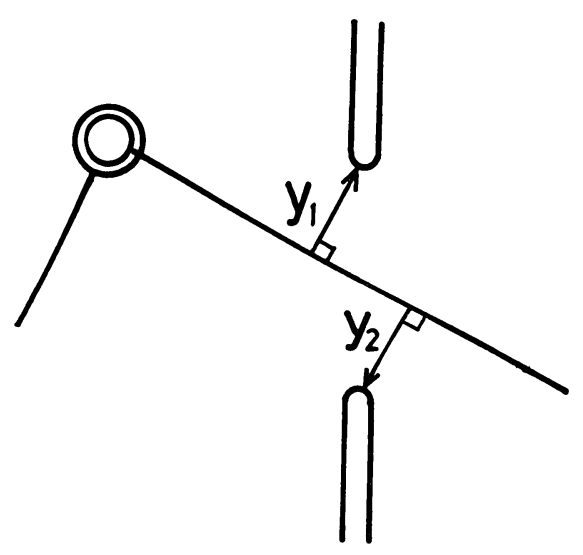

(b) Distance between Arm and Obstacle, $y_{1}, y_{2}$

Fig.4 2-link Manipulator $\left(l_{1}=0.9, \quad l_{2}=0.75\right)$

$$
J H=P \Lambda Q^{T}
$$

ここで,

$$
\begin{aligned}
& \Lambda=\left(\begin{array}{cccccc}
\lambda_{1} & & & & \vdots \\
& \lambda_{2} & & & \vdots \\
& & \cdots & & \vdots \\
& & \cdots & & \vdots \\
& & & & \lambda_{m}
\end{array}\right) \in R^{m \times(n-r)} \\
& \lambda_{1} \geqq \lambda_{2} \geqq \cdots \geqq \lambda_{m} \geqq 0 \\
& P=\left[\boldsymbol{p}_{1}, \boldsymbol{p}_{2}, \cdots, \boldsymbol{p}_{m}\right]
\end{aligned}
$$

であり, $P \in R^{m \times m}, Q \in R^{(n-r) \times(n-r)}$ は直交行列である. 前節の議論から分かるように, 楕円体 $S_{A}$ の主軸は $\lambda_{1} \boldsymbol{p}_{1}, \lambda_{2} \boldsymbol{p}_{2}, \cdots, \lambda_{m} \boldsymbol{p}_{m}$ で与えられる.

本研究では，(14）式で示す拘束条件下における可操 作度 $\boldsymbol{q}_{\boldsymbol{A}}$ を, この棈円体 $S_{A}$ の体積に対応する量とし,

$$
q_{A}=\lambda_{1} \lambda_{2} \cdots \lambda_{m}
$$

と定義することにする.

例 1

Fig. 1 の 3 リンクマニピュレータを用いて, Fig. 3 （a）に示すような姿勢で作業をしたとき，本節で定義 した可操作性棈円体がどのようになるかを示す．ただし 手先効果器のベクトル $\boldsymbol{x}$ は, 第 3 リンクの先端の $x_{1}, x_{2}$ 座標からなるものとする.

Fig. 3(a) の破線の範囲内に第 3 リンクの先端がある ときの, 可操作性棈円体の变化を Fig. 3(b) に示す. 図から分かるよらに, この程度の狭い範囲でも可操作性 䐨円体は複雑に変化している. すなわち, 拘束条件がな い場合と異なり, この程度の簡単な問題でも直感的に可 操作性を考えることが難しくなっている.

\section{4. 障害物方向への速度が制限される場合の 可操作性楕円体および可操作度}

\section{1 許容される関節速度の集合 $\boldsymbol{P}_{B}$}

マニピュレータと障害物の接近が $q$ 力所 $(q \leqq n)$ で起 きている場合を考える. 各場所に利将る接近速度 $\dot{y}_{\imath}$ え まとめて表すべクトルを $\dot{\boldsymbol{y}} \in R_{q}$ とする，本節では，こ の速度が次のように制限される場合を考える.

$$
\left|\dot{y}_{i}\right| \leqq v_{i \max } \quad i=1,2, \cdots, q
$$

上式を満たす速度べクトル $\dot{\boldsymbol{y}}$ の集合は, $q$ 次元空間に おける直方体となる.

一例として, Fig. 4(a) に示すよらに, 障害物の隄 間から 2 リンクのマニピュレータを差し込んで作業する 場合を考える. このとき Fig. 4(b) から分かるように マニピュレータは障害物と 2 力所で接近を起こしている. この場合接近距離 $y_{1}, y_{2}$ は図のよらに定義され, 接近 速度 $\dot{y}_{1}, \dot{y}_{2}$ はその時間変化として定義される.

（26）式のように制限を与えた場合, 接近速度と遠ざ かる速度の両方を拘束していることになる. 遠ざかる場 合に関しては必ずしも拘束する必要はないが，可操作性 棈円体を計算する便宜を考え，また安全側の評価を得る ためこのようにした.

さらに（26）式を近似することを考える.（26）式の

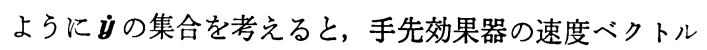
の集合を求めるための計算が非常に複雑になり, また得 られる集合も桎円体とはならない. そこで，(26）式で

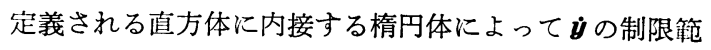
囲を近似することにする.すなわち

$$
\dot{\boldsymbol{y}}^{T} W \dot{\boldsymbol{y}} \leqq 1
$$


関節速度 $\dot{\boldsymbol{\theta}}$ と $\dot{\boldsymbol{y}}$ の関係は次のよらに表されるものと する.

$$
\dot{\boldsymbol{y}}=F \dot{\boldsymbol{\theta}}, F \in R^{q \times n}
$$

たたし， $\operatorname{rank} F=q$ とする.（28）式を（27）式に代入 することにより次式が得られる.

$$
\dot{\boldsymbol{\theta}}^{T} F^{T} W F \dot{\boldsymbol{\theta}} \leqq 1
$$

許容される関節速度べクトルの集合 $P_{B}$ は, 関節が本

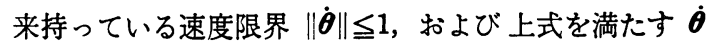
からなる.すなわち

$$
P_{B}=\left\{\dot{\boldsymbol{\theta}} \mid \dot{\boldsymbol{\theta}}^{T} F^{T} W F \dot{\boldsymbol{\theta}} \leqq 1\right\} \cap\{\dot{\boldsymbol{\theta}} \mid\|\dot{\boldsymbol{\theta}}\| \leqq 1\}
$$

上式から分かるように, 集合 $P_{B}$ は多くの場合棈円体と はならず，複雑な形になる.

\section{4. $2 P_{B}$ に内接する棈円体 $P_{B}{ }^{\prime}$ の誘章}

次に，(30）式で定義される許容関節速度べクトルの 集合 $P_{B}$ を, より計算に便利な集合で近似することを考 える. その集合として $P_{B}$ に内接する棈円体 $P_{B^{\prime}}$ を採 用することにする．本節では，この $P_{B}^{\prime}$ の誘導につい て述べる。

関節速度の空間 $\dot{\Theta} は$, 行列論のよく知られた性質から 次のように分解することができる.

$$
\begin{aligned}
& \dot{\Theta}=\operatorname{Null}(F) \oplus \operatorname{Range}\left(F^{T}\right) \\
& \operatorname{Null}(F) \perp \operatorname{Range}\left(F^{T}\right)
\end{aligned}
$$

ただし， $\operatorname{Null}(F)$ は $F$ の零空間を意味し， $\operatorname{Range}\left(F^{T}\right)$ は $F^{T}$ の值域を意味する。 また，丹は直和を意味する。

（31）式から明らかなように, 任意の $\dot{\boldsymbol{\theta}} \in \dot{\Theta}$ は

$$
\begin{gathered}
\dot{\boldsymbol{\theta}}=\dot{\boldsymbol{\theta}}_{N}+\dot{\boldsymbol{\theta}}_{R} \\
\left\{\begin{array}{c}
\dot{\boldsymbol{\theta}}_{N} \in \operatorname{Null}(F) \\
\dot{\boldsymbol{\theta}}_{R} \in \operatorname{Range}\left(F^{T}\right)
\end{array}\right.
\end{gathered}
$$

と，一意に表すことができる.（29）式に（33）式を代 入すると， $\dot{\theta}_{N}$ の項は消立次式が得られる.

$$
\dot{\boldsymbol{\theta}}_{R}{ }^{T} F^{T} W F \dot{\theta}_{R} \leqq 1
$$

すなわち，(29）式は， $\dot{\boldsymbol{\theta}}_{R}$ のみに制限を与えるものであ り， $\dot{\boldsymbol{\theta}}_{N}$ に対しては何の制限にもなっていないことが分 かる.

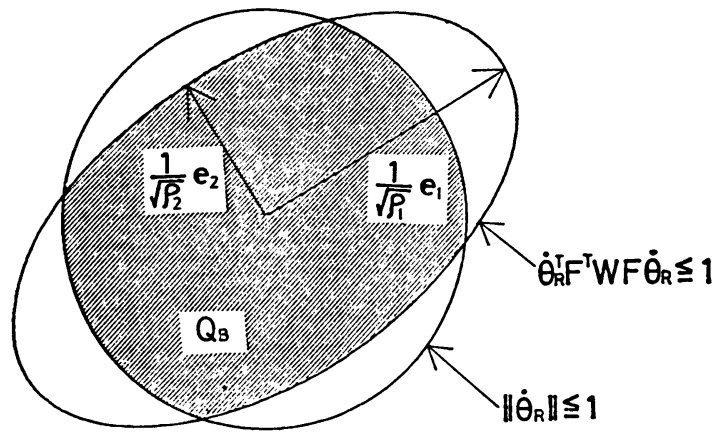

(a) $Q_{P}$ $\left\|\dot{\theta}_{R}\right\| \leqq 1$

Fig. 5 Set of Admissible Joint Velocity Vectors in Range $\left(F^{T}\right)$
そこで, $\operatorname{Null}(F)$ と Range $\left(F^{T}\right)$ に分けて議論を行 5. $\dot{\theta}_{R}$ を含む空間である Range $\left(F^{T}\right)$ における議論を 最初に行う．この空間上では，関節速度の制限 $\|\dot{\theta}\| \leqq 1$ は $\left\|\dot{\boldsymbol{\theta}}_{R}\right\| \leqq 1$ と表される. (35) 式および $\left\|\dot{\boldsymbol{\theta}}_{R}\right\| \leqq 1$ を満 たす Range $\left(F^{T}\right)$ に拈ける集合を $Q_{B}$ とする. すなわ ち,

$$
Q_{B}=\left\{\dot{\theta}_{R} \mid \dot{\theta}_{R}{ }^{T} F^{T} W F \dot{\theta}_{R} \leqq 1\right\} \cap\left\{\dot{\theta}_{R} \mid\left\|\dot{\theta}_{R}\right\| \leqq 1\right\}
$$

上式の右辺第 1 項の集合は, Range $\left(F^{T}\right)$ に护ける棈 円体であり，その主軸は次のようにして計算できる7). $F^{T} W F$ には $q$ 個の正の固有値 $\rho_{1}, \rho_{2}, \cdots, \rho_{q}$ と $n-q$ 個 の零固有値がある. 正の固有値 $\rho_{1}, \rho_{2}, \cdots, \rho_{q}$ に対する固 有ベクトルを正規化したすのを $\boldsymbol{e}_{1}, \boldsymbol{e}_{2}, \cdots, \boldsymbol{e}_{q}$ とする. こ のとき

$$
e_{1}, e_{2}, \cdots, e_{q} \in \operatorname{Range}\left(F^{T}\right)
$$

である. また， $F^{T} W F$ は実対称行列なので $\boldsymbol{e}_{1}, \boldsymbol{e}_{2}, \cdots, \boldsymbol{e}_{q}$ は互いに直交している．（35）式を満たす棈円体の主朝 は, $\left(1 / \sqrt{\rho_{1}}\right) e_{1},\left(1 / \sqrt{\rho_{2}}\right) e_{2}, \cdots,\left(1 / \sqrt{\rho_{q}}\right) e_{q}$ によってちら れる7).

Range $\left(F^{T}\right)$ が 2 次元の場合の $Q_{B}$ の例を Fig. 5(a ) に示す. $Q_{B}$ は困中の斜線で示される領域である.この 例から分かるように， $Q_{B}$ の形は複雑なので，Fig. 5(b) に斜線で示すように内接する棈円体で近似することを考 え，その集合に $Q_{B}{ }^{\prime}$ といら名前をつけた. Fig. 5(b)に は2 次元の例を示したが，このような棈円体 $Q_{B}{ }^{\prime}$ は一 般には次のように与えられる.すなわち, 棈円体 $Q_{B}{ }^{\prime}$ の主軸は

$$
\alpha_{1} e_{1}, \alpha_{2} e_{2}, \cdots, \alpha_{q} e_{q}
$$

で与えられる.ただし

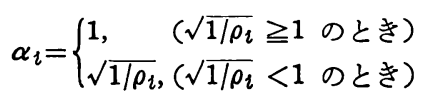

次に, 部分空間 $\operatorname{Null}(F)$ において, $\|\dot{\boldsymbol{\theta}}\| \leqq 1$ 及び (29) 式を満たす関節速度の集合を求める. しかし，(29）式 は，前述のように $\operatorname{Null}(F)$ の要素である $\dot{\theta}_{N}$ に対して

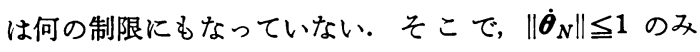

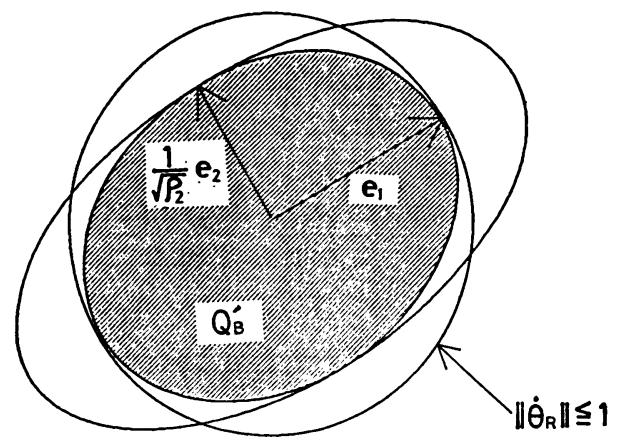

(b) $Q_{B^{\prime}}$ 
を満たす集合を求めればよいすななわち， $\operatorname{Null}(F)$ に おける許容関節速度ベクトルの集合は, $\operatorname{Null}(F)$ の正 規直交基底 $d_{1}, d_{2}, \cdots, d_{n-q}$ を主軸とする棈円体 $R_{B}$ す なわち球として与えられる.

以上の議論では， Range $\left(F^{T}\right)$ および $\operatorname{Null}(F)$ にお。 ける許容関節速度へクトルの集合をそれぞれ棈円体 $Q_{B}{ }^{\prime}$ および $R_{B}$ として得た. $\dot{\theta}$ における許容関節速度へク トルの集合 $P_{B}{ }^{\prime}$ としては， $Q_{B}{ }^{\prime}$ および $R_{B}$ の主軸をそ の主軸とする棈円体を選ぶことにする，すなわち， $P_{B^{\prime}}$ の主軸は, $d_{1}, d_{2}, \cdots, d_{n-q}, \alpha_{1} e_{1}, \alpha_{2} e_{2}, \cdots, \alpha_{q} e_{q}$ よりな る.

また， 棈円体 $P_{B}{ }^{\prime}$ は， 2 節の議論から分かるように， 次のようにも表せる.

$$
P_{B^{\prime}}=\{\dot{\boldsymbol{\theta}} \mid \dot{\boldsymbol{\theta}}=G \Gamma \boldsymbol{\xi},\|\boldsymbol{\xi}\| \leqq 1\}
$$
ただし，

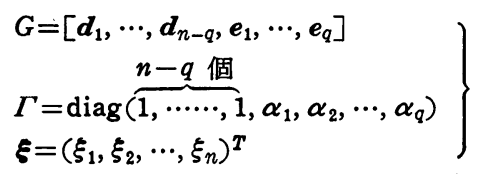

最後に，上記のようにして求めた $P_{B}{ }^{\prime} か ゙ P_{B}{ }^{\prime} \subseteq P_{B}$ を満 たすかどらかを確認する。すすなわち， $P_{B}^{\prime}$ に含まれる任

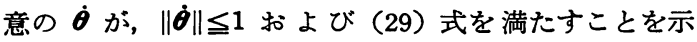
す. これらの式の左辺に $\dot{\theta}=G \Gamma \xi$ を代入すると, 次の ようになる。

$$
\begin{aligned}
\|\dot{\boldsymbol{\theta}}\|^{2} & =\xi^{T} \Gamma^{T} G^{T} G \Gamma \xi \\
& =\xi_{1}{ }^{2}+\cdots+\xi^{2}{ }_{n-q}+\alpha_{1}{ }^{2} \xi^{2}{ }_{n-q+1}+\cdots+\alpha_{q}{ }^{2} \xi_{n}{ }^{2}
\end{aligned}
$$

\section{$\dot{\boldsymbol{\theta}}^{T} F^{T} W F \dot{\boldsymbol{\theta}}=\boldsymbol{\xi}^{T} \Gamma^{T} G^{T} F^{T} W F G \Gamma \boldsymbol{\xi}$}

$$
=\alpha_{1}^{2} \rho_{1} \xi^{2}{ }_{n-q+1}+\cdots+\alpha_{q}^{2} \rho_{q} \xi_{n}{ }^{2}
$$

ゆえに, $\|\boldsymbol{\varepsilon}\| \leqq 1$ であれば, $\|\dot{\boldsymbol{\theta}}\| \leqq 1$ および（29）式が 成り立つ。

\section{3 可操作性棈円体 $\boldsymbol{S}_{B}$}

$P_{B^{\prime}}$ に含まれる関節速度へクトル $\dot{\theta}$ によって実現す ることのできる手先効果器の速度べクトル $\dot{\boldsymbol{x}}$ のすべて の集合は次のようにして表される.

$$
S_{B}=\{\dot{\boldsymbol{x}} \mid \dot{\boldsymbol{x}}=J G \Gamma \boldsymbol{\xi},\|\boldsymbol{\varepsilon}\| \leqq 1\}
$$

前節の議論と同様にして, 行列 $J G \Gamma$ を特異值分解す ることにより, 可操作性榇円体 $S_{B}$ の主軸は決定できる.

本研究では, (27) 式の拘束条件下にある可操作度 $q_{B}$ を, この楕円体 $S_{B}$ の体積に対応する量とし，

$$
q_{B}=\gamma_{1} \gamma_{2} \cdots \gamma_{m}
$$

と定義することにする．ただし， $\gamma_{1} \gamma_{2} \cdots \gamma_{m}$ は行列 $J G \Gamma$ の特異値である.

例 2

Fig. 4(a) に示す障害物の隙間からマニピュレータを 差し込んで作業する例について考え，本節で定義した可

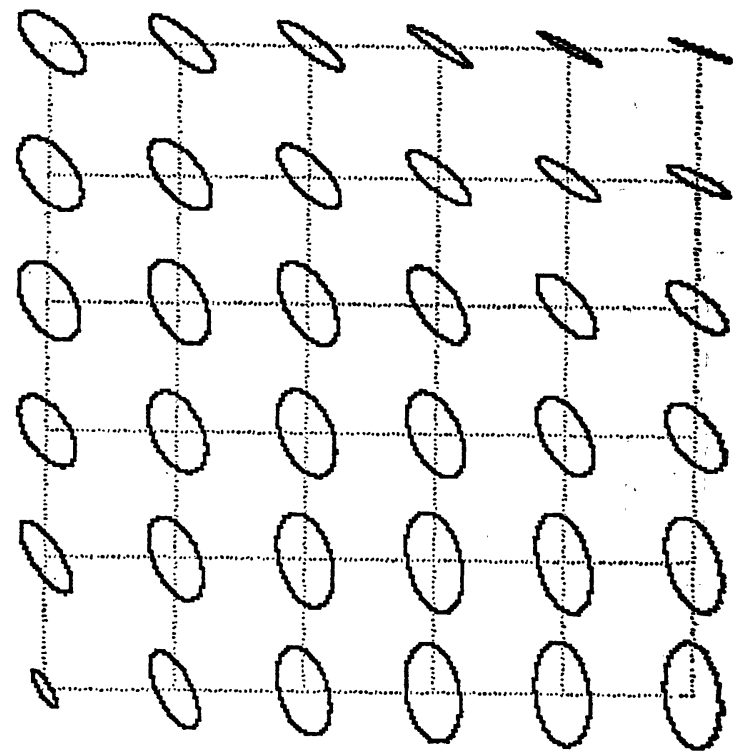

Fig. 6 Manipulability Ellipsoid, $S_{B}$

操作性棈円体を求めてみる.

接近速度に関する制限は，距離が近いほど䈔しくし， 次のように設定する.

$$
\dot{y}_{\imath}^{2} \leqq a_{\imath}{ }^{2} y_{\imath}{ }^{2} \quad i=1,2
$$

このとき, (27) 式の $W$ は

$$
W=\left[\begin{array}{cc}
1 / a_{1}^{2} y_{1}^{2} & 0 \\
0 & 1 / a_{2}^{2} y_{2}^{2}
\end{array}\right]
$$

となる.

ここでは, Fig. 4(a) の破線の範团内でマニピュレー タの先端を動かすことを考える.この範囲内において本 節で定義した可操作性棈円体 $S_{B}$ を Fig. 6 に示す.た だし， $a_{1}=a_{2}=6$ とした。

\section{8 リンクマニピュレータによる障漂 物回避制御}

3 節で定義した可操作度を考虑してマニピュレータの 制御を行った例を示す. Fig. 7 に示すよらな関節構成 を持つ 8 リンクマニピュレータを用いてシミュレーショ ンおよび実験を行った．この実験では，Fig. 8 に示す ように, 細長いスリットの間にマニピュレータを差し込 んで，把持したパイプを一定の方向に向けながら直線に 沿って移動させた。この実験では，マニビニレータがス リットの中央を通過する必要があるといら拘束条件を設 定した.この拘束条件を満たすため, 手先効果器の位置, 及び方向を表すべクトル $\boldsymbol{x}$ を以下の上らに払張する，ス リットの中央からのマニピニレータのずれを表す変数を $x_{z}$ とし， $\boldsymbol{x}$ を払張したべクトルを $\boldsymbol{x}$ と定義する．すな わち, 


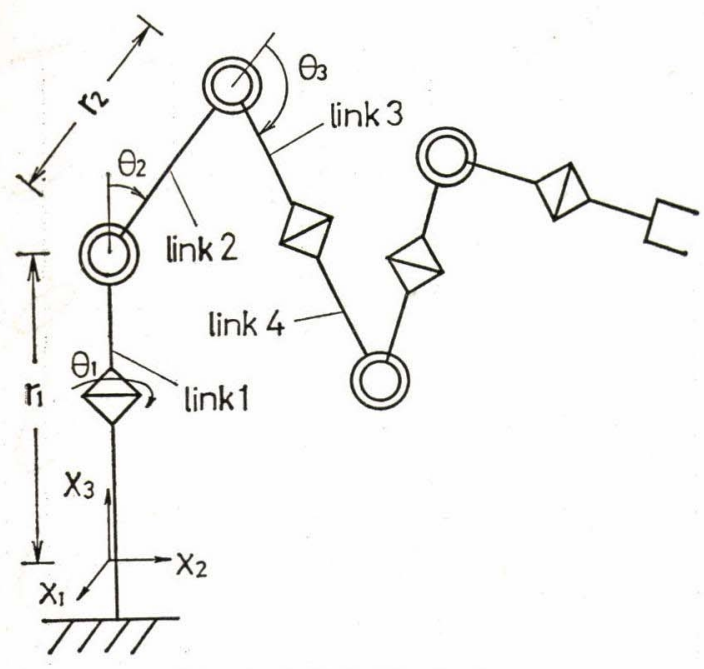

Fig. 7 -link Manipulator

$$
\bar{x}=\left[x^{T}, x_{7}\right]^{T}
$$

関節角度ベクトル $\boldsymbol{\theta}$ と $\bar{x}$ の関係を

$$
\overline{\boldsymbol{x}}=\overline{\boldsymbol{f}}(\boldsymbol{\theta})
$$

と表す.このとき, 次式が成り立つ.

$$
\dot{\overline{\boldsymbol{x}}}=\overline{\mathrm{J}} \dot{\boldsymbol{\theta}}
$$

ここで $\bar{J}=\partial \overline{\boldsymbol{f}}(\boldsymbol{\theta}) / \partial \boldsymbol{\theta} \in R^{7 \times 8}$ である.

$\bar{J}$ は $7 \times 8$ 行列なので, 文が与えられたとき, $\dot{\boldsymbol{\theta}}$ を一 意に決定することはできない，このて長性を有効に利用 して，3 節で定義した可操作度 $q_{A}$ を大きな值に 保持 しながら軌道を制御することを考える. その方法として,

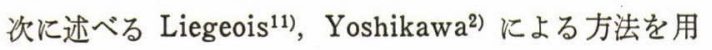
いる.

（48）式に関する $\dot{\boldsymbol{\theta}}$ の一般解は次のように表される.

$$
\dot{\boldsymbol{\theta}}=\bar{J}^{+} \dot{\boldsymbol{x}}+\left(I-\bar{J}^{+} \bar{J}\right) \boldsymbol{k}
$$

ただし， $\bar{J}^{+}$は $\bar{J}$ の擬似逆行列であり， $\boldsymbol{k}$ は任意の 8 次ベクトルである. この $\boldsymbol{k}$ の任意性を利用して， 3 節で 定義した可操作度 $q_{A}$ を大きな值に保持することを考え る.

$$
\begin{aligned}
\text { そのため, } \boldsymbol{k} \text { を次のように選ぶ. } \\
\qquad \boldsymbol{k}=\left\{\partial q_{A}(\boldsymbol{\theta}) / \partial \boldsymbol{\theta}\right\}^{T} k_{p}=\boldsymbol{\zeta} k_{p}
\end{aligned}
$$

ここで, $\boldsymbol{\zeta}=\left\{\partial q_{A}(\boldsymbol{\theta}) / \partial \boldsymbol{\theta}\right\}^{T}$ とする.

ただし， $k_{p}$ は適当な 正の数に選ぶことのできる調節 パラメータである. このように $\boldsymbol{k}$ を選ぶと， $\dot{q}_{A}$ は次の ように表される。

$$
\dot{q}_{A}=\boldsymbol{\zeta}^{T} \bar{J}^{+} \dot{\boldsymbol{x}}+\boldsymbol{\zeta}^{T}\left(I-\bar{J}^{+} \bar{J}\right) \boldsymbol{\zeta} k_{p}
$$

$\left(I-\bar{J}^{+} \bar{J}\right)$ は非負定行列であるので, 上式の右辺第 2 項 は常に非負である. すなわち，(50）式のように $\boldsymbol{k}$ を選 ぶと, 上式の右辺第 2 項は, 評価 $q_{A}$ を大きくする方向 に常に作用する ${ }^{2,9)}$.
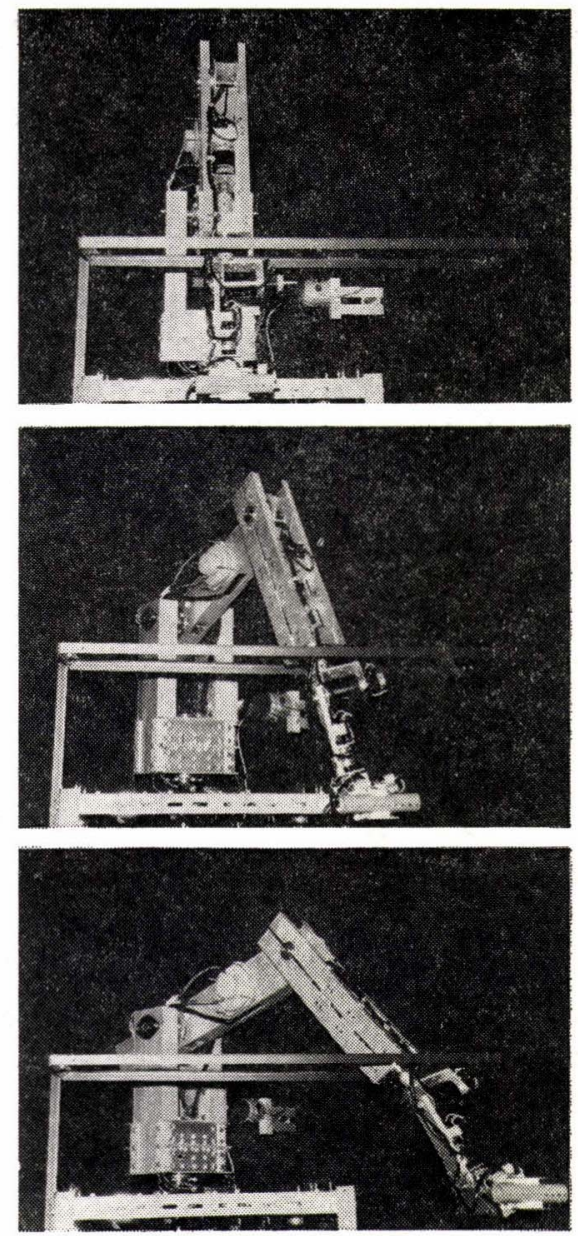

Fig. 8 Experimental Results

関節速度 $\dot{\boldsymbol{\theta}}$ に対する拘束条件式 (14) の行列 $\boldsymbol{B}$ を具体 的に以下で求めて扰く. スリットの中央の座標は $x_{1}=$ $x_{1 s}, x_{3}=x_{3 s}$ で与えられるものとする. また，第 3 リン クおよび第 4 リンクの中心軸がこのスリットの中央を通 るという問題設定とする.

本マニピュレータでは第 1 , 第 2 リンクの中心軸は, それらのリンク間の回転軸と同一の点で交わっている. また第 2 リンク，第 3 リンクについてもこの性質が成り 立っているので, 行列 $\boldsymbol{B}$ の形は比較的簡単になり次のよ らになる.

$$
\begin{aligned}
\boldsymbol{B}= & {\left[s_{1} s_{3} r_{2}-s_{1} s_{23}\left(x_{3 s}-r_{1}\right),\right.} \\
& s_{23} x_{1 s}+c_{1} c_{23}\left(x_{3 s}-r_{1}\right), \\
& s_{23} x_{1 s}+c_{1} c_{23}\left(x_{3 s}-r_{1}\right)-c_{1} c_{3} r_{2}, \\
& 0,0,0,0,0]
\end{aligned}
$$

ここで, $r_{1}, r_{2}$ は Fig. 7 に定義するものである. ま た, $c_{1}=\cos \left(\theta_{1}\right), c_{23}=\cos \left(\theta_{2}+\theta_{3}\right), s_{3}=\sin \left(\theta_{3}\right), s_{23}=\sin$ $\left(\theta_{2}+\theta_{3}\right)$ とする. 
Fig. 8 に示したマニピュレータの動きは $k_{p}=10$ とし た場合である、このときの真上からみたアームの動きを スティック線図で表したのが，Fig.9（a）である。ま た Fig. 9(b) には，ハンドの $x_{2}$ 座標を横軸としたと きの可操作度 $q_{A}$ の変化を示す. 図から分かるように, $q_{A}$ は急激に大きくなり，その後それ汪ど小さくなって いない.

Fig. 10 には， $k_{p}=0$ とした時のスティック線図およ び可操作度 $q_{A}$ の変化を示す. 図から分かるよ5に, $q_{A}$ は大きな值に保持されることがなく，最後には操作 性が著しく悪化している.

\section{6. おわりに}

マニピニレータの運動学的な操作性能を表す指標とし て従来から提案されている可操作度の概念を, 障害物の ある環境下で動作するマニピュレータに拡張した．障害 物に起因する制限条件としては 2 つの場合を考え，それ ぞれ 3 節および 4 節で論じた。

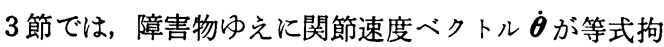
束を受ける場合を考えた.この場合のマニピュレータの

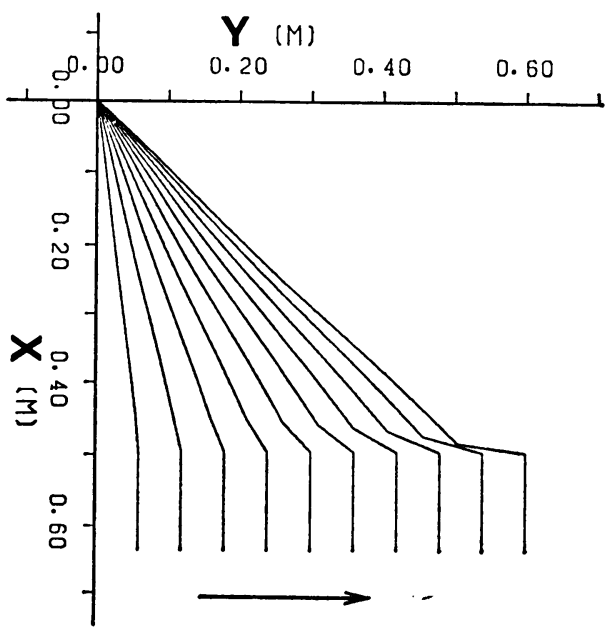

(a) Stick Diagram

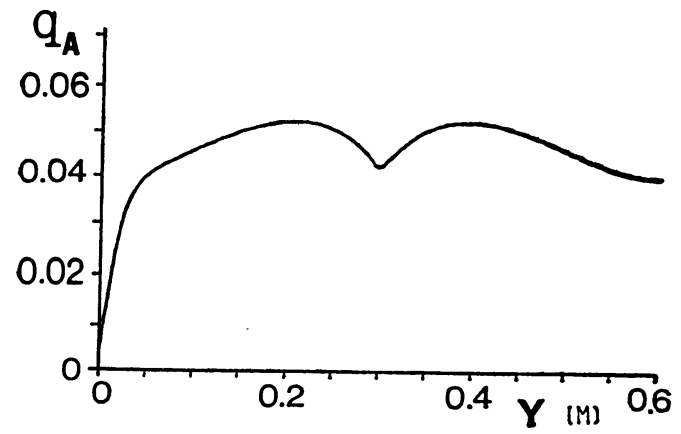

(b) Measure of Manipulability, $q_{A}$

Fig. 9 Variation of Manipulability $\left(k_{p}=10\right)$
運動学的な操作性能を表す指標として，(21）式で定義 される可操作性楕円体 $S_{A}$, 及び（25）式で定義される 可操作度 $q_{A}$ を導いた。

4 節では, 障害物方向への速度が（27）式のよらに不 等式拘束条件で，制限される場合を考えた．この場合に は, 許容関節速度べクトルの集合 $P_{B}$ は一般には棈円体 とはならないので， $P_{B}$ に内接する棈円体 $P_{B}{ }^{\prime}$ で許容関 節速度べクトルの集合を近似した．このように近似する ことにより（42）式で定義される可操作性棈円体 $S_{B}$, および（43）式で定義される可操作度 $q_{B}$ を導いた.

今後マニピュレータは種々の環境下で使われるように なり，障害物に対する配虑も益々必要になると考えられ る、しかし，障害物の影響を考虑してマニピュレータの 操作性能を評価する際には，それを直感的に知ることは 非常に難しく，定量的に表現することが必要となる。こ のような際に, 本研究で与えた可操作性楕円体や可操作 度は一つの良い目安になると考えている。

$$
\text { 謝辞 }
$$

本研究の遂行に多大なる協力をして頂いた大西悟氏 （現在，名古屋市交通局勤務）に深甚なる謝意を表します。

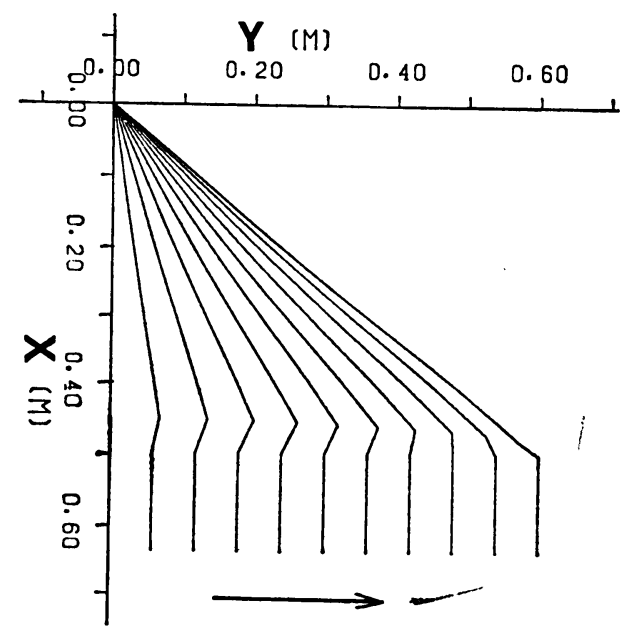

(a) Stick Diagram

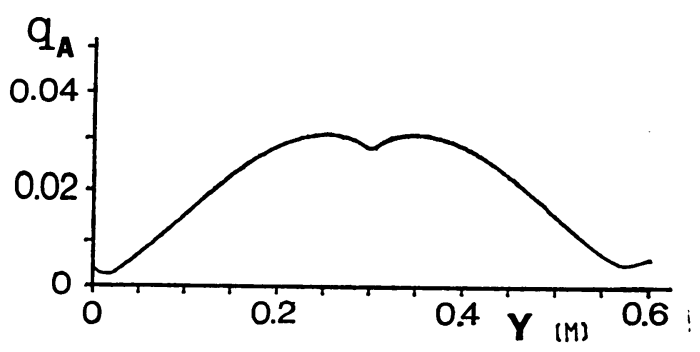

(b) Measure of Manipulability, $q_{A}$

Fig. 10 Variation of Manipulability $\left(k_{p}=0\right)$ 


\section{参考文 献}

1）吉川, “ロポットアームの可操作度”, 日本ロポット学会 誌, 2-1, pp.63-67, 1984.

2) T. Yoshikawa, "Analysis and Control of Manipulators with Redundacy", Proc. of the 1 st International Robotics research, pp.735-747, 1983.

3）内山，清水，箱守，“ヤコビ行列式によるロボットアー 么の機構評価”, 計測自動制御学会論文集, $21-2, \mathrm{pp}$. 190-196, 1985.

4) J. K. Salisbury and J. J. Craig, "Articulated hands : Force Control and Kinematic" Issues, Int. J. of Robotics Research, 1-1, pp. 4-17, 1982.

5）花房, 吉川, 中村, “関節形ロボットアームの圥長性解 析とその優先順位を有する作業への応用”, 計測自動制

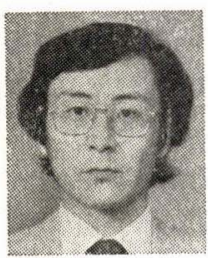

古荘純次 (Junji HURUSHO)

昭和 22 年 3 月 22 日生まれ. 45 年大阪大 学工学部産業機械工学科卒業. 50 年同大学 博士課程修了, 工学博士. 大阪大学工学部 産業機械工学科助手を経て, 現在, 岐阜大 学工学部機械工学科助教授. この間, 口ポ ット工学, プロセス制御, 多変数制御系の 設計等の研究に従事. 計測自動制御学会, 日本機械学会, バイ オメカニズム学会等の会員（日本ロボット学会正会員）

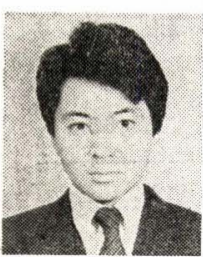

臼井広幸 (Hiroyuki USUI)

昭和 38 年 1 月 15 日生まれ. 61 年岐阜大 学工学部機械工学科卒業. 現在, 同大学大 学院工学研究科修士課程在学中 (日本ロボット学会学生会員)
御学会論文集, 19-5, pp. 421-426, 1983.

6）伊理，児玉，須田，“特異值分解とそのシステム制御 の応用”, 計測と制御, 21-8, pp. 763-772, 1982.

7) 柴岡, “線形空間”, pp. 231-241, 裳華房, 1971.

8）児玉, 須田, “システム制御のためのマトリクス理論”, pp. 155, 計測自動制御学会, 1978.

9）吉川，“圥長性を有するロボットの制御”，日本ロボット 学会誌, 2-6, pp. 587-592, 1984.

10）尾崎, “マニピニレータの障害物回避”, 日本ロボット学 会誌, 2-6, pp. 580-586, 1984.

11) A. Liegeois, "Automatic Supervisory Control of the Configuration and Behavior of Multibody Machanism", IEEE Trans. Vol. SMC-7, No.12, pp. 868$871,1977$.

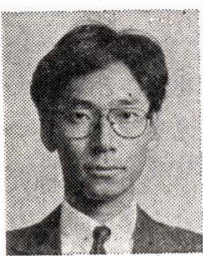

佐野明人 (Akihito SANO)

昭和 38 年 2 月 8 日生まれ。 62 年 3 月岐 阜大学大学院工学研究科修士課程修了. 局 年 4 月岐阜大学工学部機械工学科助手. 現 在に至る. ロポット工学の研究に従事. 日 本機械学会, 計測自動制御学会の会員

(日本ロボット学会正会員)

\title{
Manipulability of Robotic Manipulators Considering the Influence of Obstacles*
}

\author{
Junji FURUSHO** Hiroyuki USUI** Akihito SANO**
}

It is useful for control of robot manipulators and for task planning if we have a quantitative measure of manipulating ability in positioning and orienting the endeffectors. In this paper, a method for estimating the ability of robot manipulators under the environment with obstacles is proposed from the viewpoint of kinematics.

The obstacles which are close to a manipulator bring some restrictions to the motion of the manipulator. In this paper, we discuss two cases; the one is the case that the joint velocity vector must satisfy the equality constraint for the purpose of avoiding the obstacle, and the other is the case that the approaching speed to the obstacle is restricted. For each case, we derive a manipulability ellipsoid and a measure of manipulability. Lastly, as an example, an experiment and simulation results using an eight degree of freedom manipulator are shown. In this experiment, the endeffector is inserted into an inside space through a narraw slit, and the joint angle velocities are controlled so as to keep the proposed manipulability large.

Key Words : Robot Arm, Kinematic Evaluation, Manipulability, Obstacle Avoidance, Task Planning

* Received September 16, 1987

** Faculty of Engineering, Gifu University 